\title{
Gender Roles in The Merchant of Venice and Othello
}

\author{
Saed Shahwan \\ Department of English, University of Hail, Hail, Saudi Arabia
}

\begin{abstract}
Literature enables authors to express various societal matters. Shakespeare provides a wide range of information from the Elizabethan era through his works. An important issue that is evident in his work is gender roles. The roles of characters, as described by Shakespeare, show social norms that define female and male genders. Female characters in Shakespeare's Merchant of Venice and Othello are underestimated because of the stereotypical gender roles. The roles involving female characters revolve around the homestead, unless where a female character is from a wealthy family, a queen or a princess. Male dominance in society implies that the Shakespearean era advocated for women discrimination.
\end{abstract}

Index Terms — gender roles, femininity, masculinity, discrimination, gender equality

\section{INTRODUCTION}

Every society has role expectations depending on gender, culture, and social changes. During the time when Shakespeare was alive and writing his works, there were norms about gender and sexuality like there are in today's society. Shakespeare's work has various gender and sexuality roles (Russin, 2013, p.116) depending on the play, where the author uses gender or sexuality as a tool of propaganda or manipulation. However, the gender and sexuality roles in Shakespeare's work represent the norms of society during his period. Shakespeare presents a hierarchy of sexes with defined roles. Shakespeare presented men as strong and in charge of the ruling. Female characters belonged in the household, with their duties being confined in the homestead. The presentation of sexuality and gender in Shakespeare's work represents the societal view and the authors understanding of the subject matter. Shakespeare deconstructs the blurring connection between gender and sexuality, creating ambiguity about the two. Shakespeare presents contradictory characters based on gender roles, whereby female characters perform a dominantly men role, while men perform feminine roles. Although the issue of sexuality and gender as represented by Shakespeare comes from societal norms, analysts of gender matters identify gender roles as biased. The role of women in society (Russin, 2013, p.117), as presented by Shakespeare, discriminates against women because of the male characters having authority over the females. Looking at Shakespeare's plays demonstrate that women had less freedom compared to their male counterparts. During Shakespeare's time, women did not take part in stage acts making them not be heard or seen. The place of women in traditional society was in homesteads, making them not have social activities outside the homestead. However, Shakespeare's plays demonstrated how women significantly influenced their husbands, making their views and demands felt across society. The plays expressed varying expectations and demands from women $r$ wives from the upper class and lower class. Women from the upper class had higher value compared to women from the lower class. Shakespeare's plays the Merchant of Venice, and Othello paints a picture of gender roles and sexuality during Shakespeare's time. Female and male characters in these plays perform gender roles that reflect the norms of society. However, some female characters demonstrate the desire and determination to overcome societal discrimination. The gender roles described by Shakespeare are inconsistent with the changing societal norms, making the roles face criticism from feminists and modern society (Shahid, 2013).

\section{LITERATURE REVIEW}

Social practices predominant in modern society determine the masculine and feminine characteristics. The gender stereotypes in society are represented by the male and female characters consistent with their gender. A man or woman in society entails the awareness of gender roles and not just having diverse anatomical features (Palahniuk, 2015). Gender role realization highlights the need to reconsider men's and women's roles in society. Male and female biological terms are distinguished by gender study with sociologically determined terms of masculine and feminine (Walmiki, 2017). Gender study principles are, therefore, based on the social practices prevalent in society. The gender equality of an ideal female character for the period of Elizabethan England was an upright, dedicated, silent, obedient, and innocent woman. Society's socio-cultural norms offer men and women's emotional qualities, occupations, and behaviour (Palahniuk, 2015, p.75). The characters in Merchant of Venice possess stereotypes that describe societal gender roles (Strickler, 2005, p. 120). The female characters challenge traditional negative stereotypes of discrimination, weakness, and silence. Feministic values are greatly evident throughout the Merchant of Venice. Toughness and strength are connected with masculinity, whereas gentleness and weakness are connected with femininity. 
In judgment and decision-making, women are considered helpless and require male guidance, but Shakespeare attempts to challenge this notion. Women's freedom was not esteemed, and their male counterparts were well-regarded as more superior. Women were raised to become good child-bearers and responsible housekeepers. Performing household tasks, bearing and rearing children was a responsibility placed upon women. In Elizabethan order, female characters were expected to remain obedient and silent to their fathers and husbands. The author deviated from this model, and his eloquent female characters did not conform to it. In Shakespeare's Merchant of Venice and Othello, characters have stereotypes that define societal gender roles (Nimavat, 2017, p. 147). Gender roles begin from an early age, and the father figure is considered the principal main source of income. In Merchant of Venice and Othello, there were powerful female characters that proved equal to men. Shakespeare shapes his female roles as powerful and confident instead of inferior to the male equivalent. As Shakespeare implies, the three female characters do not imitate the societal standards following guidelines about wives' roles. The female characters focus on challenging the old-style negative stereotypes of discrimination, inexperience, weakness, and silence. The common Elizabethan gender stereotypes are challenged by the author's dominant depiction of women. Shakespeare advocated for gender equality and considered none superior to the other.

Gender in society is a fundamental factor in determining collective societal standards. Gender norms are a division of social norms, and they often change and from culture to culture (Tasmia, 2016). The only socially tolerable positions for women in the Elizabethan time were marriage and monastery. In the Elizabethan order, women were considered inferior and taught house management chores, chastity values, silence, and obedience. William Shakespeare was fundamental in challenging the subservient roles of women, and he makes use of female characters that are rebellious against society's norms for this achievement. The author portrays his female protagonists as victims of a patriarchal culture.

All the chief female characters in the Merchant of Venice and Othello symbolize gender inferiority, discrimination, and victimization. Due to shifting social values in a patriarchal society, women emerge courageous, intelligent and greatly influence their male counterparts. Consequently, female characters who have endured excessive loads of discrimination develop modern roles in society due to the changing social values and attitudes. The women are no longer considered as properties but are honoured and esteemed, unlike in Elizabethan time (Shakespeare, 2006).

\section{Femininity}

Feminism is typically defined as promoting women's rights based on their equality (Nimavat, 2017, p. 149). A social theory intended to liberate and esteem women's power and their contribution to society constitutes feminism (Tasmia, 2016). The theory endeavours to form equal social, political, and economic rights besides equal opportunity regardless of sex. Feminism pursues eliminating the sexist concept of the subservience, discrimination, and oppression of society's women. Submission and gentleness appeared to characterize femininity in Shakespeare's period. A patriarchal society frequently obstructs the way of feminism. Feminism advocates for equal rights and no discrimination based on sex or gender.

Clear signs of male dominance characterize Venetian society. Shakespeare is defiant of the traditional gender stereotypes in The Merchant of Venice. Shakespeare existed in a patriarchal culture where power and privilege were mainly vested in men's hands (Tasmia, 2016). Great inequality was real between men and women. Shakespeare's advocacy of gender equality led to people's realization that some female characters were more spiritually and intellectually superior to their husbands yet secluded from social and political life (Nimavat, 2017, p.152). People of all genders having equal rights, opportunities, and responsibilities constitute gender equality.

More so, feminism takes various subdivisions touching on a specific area within the domain of women's inequality. Radical feminism is a key subdivision, which demands a fundamental restructuring of the society in which male supremacy or patriarchal hierarchy is abolished in economic and social backgrounds. In The Merchant of Venice, Portia is portrayed as a radical feminist considering gender as her source of discrimination and oppression. A radical feminist basically believes that her discrimination and oppression originate from a woman's gender's inferiority. Portia is stereotypically considered a radical feminist in a male-dominated society due to her high-class locality and position as a single, extremely wealthy female without a father figure (William, 2014).

\section{RESEARCH METHOD}

This research uses a qualitative method approach of analyzing literary text to identify a general theme. The research started by establishing the research topic from the primary sources, the Merchant of Venice and Othello. Many sources were used that focused on gender roles in these two primary sources. Analysis of the characters enables the identification of roles defined by gender. A review of different perspectives and interpretations of gender roles of various characters enabled an understanding of gender issues arising from the roles.

\section{FINDING AND DISCUSSION}

\section{A. Gender Roles in the Merchant of Venice}

Portia's father controlled her decision to find a husband even beyond the grave, which did not go well with her. Portia laments to her companion and maid, Nerissa, 'O me, the word 'Choose'! I may neither choose whom I would nor refuse whom I dislike. So is the will of a living daughter curbed by the will of a dead father. Is it not hard that I cannot choose 
one nor refuse none?' (Act 1, Scene 2, Line 22). Despite the lamentation, she remained submissive and obedient all through. The lamentation shows Portia's obedience and also her weakness as a female. Portia makes a silent protest for the lack of freedom to pick her husband, which the author expresses as a feminist concern (Nimavat, 2017). Portia's father's effect over her even in death is enough evidence of male dominance in women's affairs. Portia's portrayal best illustrates Shakespeare's defiance of the female stereotypes in the Merchant of Venice. Portia is brilliant, learned, and honourable and demonstrates high intellectual ability. The common Elizabethan gender stereotypes are challenged by the dominant depiction of the female characters. The three incredible female characters in the Merchant of Venice, Portia, Jessica, and Nerissa, make every effort to challenge the stereotypes that undermine their integrity in society. There is clear evidence that the female characters are subservient to their fathers and husbands in the Merchant of Venice.

However, progressively they are reflected as powerful, intelligent, and strong who speak, conduct themselves and live differently from the societal norms. To ridicule the social and gender norms of the Elizabethan order and to give a foretaste of women's capability to the Elizabethan patriarchal society, Shakespeare has anticipated resilient and confident female characters. Shakespeare's defiance to the conventional stereotype of gender roles is evident through Portia's strong and confident actions in the courtroom.

More so due to the mere fact that Portia, an apparently weak female protagonist, protects the life of a Christian man, portrays women's strong capacity to perform certain roles. The author has depicted his female characters as outspoken and strong. The female characters have a strong yearning to have equal standing with male characters. The author exhibits patriarchal domination and also an evolving protest against it. In modern rationality, the author cannot be termed as a feminist, but his humanist attitude makes him symbolize gender equality (Nimavat, 2017, p.153). A fair number of Shakespeare's female characters are outspoken, intelligent, noble, and demand equality (Tasmia, 2016). Subsequently, Shakespeare shows feminist personalities and philosophies throughout the play.

Before marriage, women were considered possessions of their fathers and, after marriage, as their husbands' possessions. Portia remained submissive in her domestic and emotional sphere. Portia had no control even over her private affairs. For example, she had to follow her father's will of picking a spouse, as sensitive as it was, indicating her father's dominance. Nevertheless, she obeyed her father's wishes even after his death. Portia demonstrates two apparently discrete identities. Originally she was subservient and obedient but subsequently proved intelligent and strong when challenging her male colleagues. Disguised as a lawyer, she uncovered a unique loophole in Antonio's case (Mahon, \& Mahon, 2013 p. 179), which she used successfully to win the case. Disguising, as a male lawyer, Portia developed into an exclusively different character, gifted and conversant in law matters unknown to the audience and assistance in solving Antonio's case. Portia's intelligence over a powerful male counterpart, expressed by her quote in the trial chambers, 'if thou dost shed one drop of Christian blood, thy lands and goods are confiscated unto the state' (Act 4, Scene 3, Line 309- 311) illustrated that women were equally able to perform male roles boldly. Portia successfully challenged the traditional stereotypical gender characteristics of her society.

Jessica was also another female personality who challenged the stereotypical women's characteristics of weakness, innocence, discrimination, and silence. Jessica's portrayal in Venice's Merchant further challenged the expectations and women's roles in the Elizabethan order. Jessica was the daughter of a well-known Jewish father, Shylock, to whom she was originally bound but later eloped with her suitor. Shylock was the most prominent male figure in Jessica's life, and her rebellion to carry on with life by her own free will was uncommon in Elizabethan order. Shylock exercised control and manipulation over Jessica, leading to her non-contentment living with him and her Jewish identity (Shahid, 2013). The non-contentment led to her elopement with Lorenzo.

Additionally, Jessica's conversion from her religion was a violation of the Jewish culture. Jessica dismissively defiled all that her father held sacred by converting to Christianity through her marriage to a Christian (Sharma, 2014). Jessica's elopement also showed disobedience on Jessica's side and against her father's will, who became very angry, hence swearing to revenge against the eloper. Running away from her dominating father, Jessica does not break the male dominance cycle because her husband, Lorenzo, became her dominating father figure. Jessica's integration into Christianity is enough evidence to prove her characteristic difference from her father. Jessica challenged the traditional gender stereotypes by going against Elizabethan women's character, disobeying, and annoying her father.

The failure to satisfy the Elizabethan society's expectations contravened the traditional gender stereotype. As such, Jessica deviated from the societal gender roles expected of her. Jessica's domestic state plagued her to the extent that she told their house servant Launcelot that, 'Our house is hell' (Act 2, Scene 3. Line 2). Shakespeare used female characters that were rebellious against society's norms, but their disloyalty challenged traditional gender stereotypes. She demonstrated strength and courage through her actions and broke from silence though she was disobedient, unlike Portia and Nerissa.

Lastly, Jessica was considered an imperfect woman for disobeying her father and failing to submit. In a great way, Jessica's actions emanated from patriarchy. She cannot run away from it because she lands into another male figure, her husband Lorenzo, whom she becomes reliant on. Jessica's quote, 'I shall be saved by my husband, he hath made me a Christian' (Act 3, Scene 5. Line 19), to Launcelot, who thinks her life is damned since her parents are Jewish, illustrates that women were heavily reliant on their male counterparts. The actions and attitudes of Portia are ironically replicated by those of Jessica (Russin, 2013). Women's weakness was also evident in Jessica's disguise as a pageboy to run away 
from her manipulative old father. Jessica's disobedience directly contrasted with Portia, who was submissive and obedient to her father even beyond his death.

Nerissa was another female personality, Portia's servant, who challenged the stereotypical women's characteristics of faintness, innocence, and silence. Together, Nerissa and Portia disguised as lawyers and clerks, respectively. Nerissa and Portia disguised as men playing the roles predominantly meant for the male to offer assistance and free Antonio from his overdue amount. The double cross-dressing showed the trust that existed between Portia and her servant. Remarkably, on all of Portia's emotional, mental, and physical escapades, Nerissa accompanied her. In terms of submission and obedience, Nerissa was generally submissive to her husband and portrayed some independence, unlike the stereotypical Elizabethan female characters.

Surprisingly, just like her mistress, Nerissa self-imposed a restriction on her marriage to Gratiano based on Portia's marriage outcome. Unlike Jessica, Nerissa followed in her mistress's footsteps. Jessica was disobedient and a total contrast to the pair. Of the three female characters, nothing or little was known about their mothers. The absent mothers rendered the female protagonists prone to vulnerability, failing to assume a strong female personality, thus, high exposure to their father's influence. Patriarchal society was characterized by the father or male members considered hubs of authority, inheritance, and decision-makers (Shahid, 2013). Through her mistress, Nerissa rose to the occasion and perceived society differently, challenging the traditional gender stereotypes.

William Shakespeare allocates male characters with stereotypical roles representing male types in society. The Merchant of Venice exposes a male-dominated society. Masculine gender role (Palahniuk, 2015, p.79) characteristics necessitate men to be aggressive, dominant, and career-oriented. However, women are perceived to be reliant on men, weaker, soft, and emotional. Masculinity is a sociological discourse socially assembled to distinguish the conduct of men and women. The central male stereotypes in the Merchant of Venice are control, masculinity, and manipulation. Unlike their female counterparts, the men of the Shakespearean time had a powerful social status. One of the most powerful societies ' institutions that describe gender roles (Aro, 2016, p.35) is patriarchy, in which women are considered subservient to men. Men are expected to be influential, balanced, and stronger than their woman counterparts to make sober decisions. Patriarchy specifies the complete rule by the male head in a family or society. The author reinforces the men's position in society as heads with various roles, authority, power, and financial matters. Examining and classifying patriarchal structure reveals that women are the most prominent characters in the Merchant of Venice (Simms, 2016).

In the Merchant of Venice, masculinity is characterized by strength, social, and financial power. In the patriarchal society, men deploy their power in family life, financial, and business matters. In Shakespeare's time, the patriarchal structure was acceptable and satisfactory.

For instance, Bassanio undermines himself from the financial perspective and feels less masculine as an unfit suitor for Portia due to his financial troubles. Bassanio is helped out financially in his courtship endeavours by Antonio through the Jewish Shylock. Portia recognizes Bassanio's sovereignty as the family head and surrenders her masculine authority and sexuality to him. Bassanio received the ring as a symbol of control over Portia and her sexuality but later failed the ring test, which he had been told never to give out. Financial power was a characteristic of masculinity in the Shakespearean era. Though Portia submitted fully to her husband, she exercised control because of her enormous wealth emotionally and psychologically (Simms, 2016). As a result of reversed roles, Portia assumed a more masculine role when disguised as a lawyer to help Bassanio's friend out of the financial crisis. Portia demonstrated masculinity by using her resources and financial capability to offer payment and bail out Antonio in the beginning.

Shylock had a strong Jewish identity and a flourishing usurer business. In Venetian society, Shylock is considered a stranger due to his double identity. Venetian was basically a Christian society. Shylock's Jewish identity and occupation as a usurer were loathed and dishonoured in the Elizabethan times (Li-hua, 2019, p.663). Shylock exercised some control due to his money lending business, but Antonio often reprimanded him about his monetary transactions and called him 'misbeliever, cut-throat dog' (Act 1, Scene 3, Lines 102-108). Shylock is disliked even by his own daughter, who elopes with a Christian. Jessica says, 'Though I am a daughter to his blood, I am not to his manners' (Act 2, Scene 3, Line 18-19). With all the scolding, a young Venetian, Bassanio, requires a loan of three thousand Ducats to woo Portia, a wealthy Venetian heiress, provided by Shylock with no interest.

Another characteristic of masculinity is demonstrated by Antonio, an influential, powerful Venetian merchant with financial interests (Russin, 2013, p.120) in overseas consignments and has invested all his money in the sea's merchant vessels. Antonio is a rich trader, honest and innocent, but his friend is poor though he loves him. Shakespeare, through Antonio, demonstrates that true faithfulness and goodness are compensated in life. Antonio was a faithful and generous friend. In Merchant of Venice, masculinity is characterized by financial stability that enables men to control many affairs.

Additionally, Portia demonstrates eloquence by organizing a detailed victory in Antonio's case with practical coherence and an unbelievable masculine self-confidence. More often, Shakespeare used disguise devices in his plays. Also disguised as lawyer Balthasar, Portia asks Bassanio the engagement ring she had given him. Bassanio fails the loyalty test because of an earlier agreement that should he give away the engagement ring, he would have lost control over her also. Portia, by outwitting Bassanio, recuperates full control of him, and in the end, she regains social power 
over any of the male characters (Tasmia, 2016). Portia successfully challenged traditional gender stereotypes and also influenced her servant Nerissa to do the same.

Portia's role as a lawyer depicts her wisdom, strength, and confrontational skills. In a patriarchal society, the male characters want to control women and limit their freedom, but the women challenge some control. The women in The Merchant of Venice possess well discerning capabilities despite male prejudice and conformity to Elizabethan gender stereotypes. Portia often portrays powerful eloquent characteristics concerned with gender issues and approaches life from a distinctly feminist viewpoint (Calvo, 2014, p.51). Nerissa and Portia are aware that men are perceived as superior, but that does not prevent them from pursuing their purposes. The two courageously took on men's roles and exercised masculinity disguised in men's attires in the courtroom, and successfully emerged victorious in Antonio's case.

William Shakespeare has challenged the notion that women are significantly superior to women. The author uses cross-dressing in his writings since clothing reveals people's distinguished personalities according to gender, social position, and race. Cross-dressing involved gender shift, and women's roles were assigned to young male trainees called pageboys, whereas young females took men's roles in Shakespeare's time. People can disguise themselves through clothing and perform roles meant for the other gender.

Additionally, cross-dressing shifts a personality's identity, as seen in Portia's and Nerissa's behaviour that amazingly changes when they appear in court wearing male outfits. Portia and Nerissa cross-dress and leave Belmont and enter the masculine world of men to protect Antonio and Bassanio from Shylock. Portia and Nerissa cross-dresses, effortlessly slip into their masculine roles, and demonstrate great court expertise that the audience was unaware of (Tasmia, 2016). By shifting socially determined outfits, the female protagonists could undermine the traditional gender roles bestowed upon them (Shahid, 2013). Cross-dressing allows Portia and Nerissa the opportunity to carry out the tasks they could never accomplish otherwise. The idea of women disguising in men's outfits was to achieve an equal role as men. Socially through cross-dressing, women would turn into men shifting their identities and developing masculinity in them.

Again, pseudo-identity gives women the chance to counter-attack patriarchy (Shahid, 2013). The Shakespearean age men have a great influential status, as seen in Jessica's newfound freedom and power when she is dressed as a pageboy. Jessica's use of a pageboy's outfit helps accomplish the escape mission from her father. By disguising as male characters, the female can accomplish remarkable roles meant for men. Shakespeare demonstrates the rewards of being male in a patriarchal society through cross-dressing. The use of male outfits provides enablement for the weaker female protagonists. The role played by Portio as a lawyer demanded cross-dressing as a man in the Elizabethan era. The three female protagonist's usage of cross-dressing to accomplish various roles they could not in their outfits was paramount.

\section{B. Gender Roles in Othello}

William Shakespeare's tragedy Othello presents various gender roles depending on the type of character. The characters in Othello have stereotypes that define societal gender roles. The male and female characters in Shakespeare's Othello represent the gender stereotypes in society consistent with their gender, although female characters, such as Emilia and Desdemona, attempt to challenge some stereotypes that undermine their position in society.

Female characters in Othello are considered intellectual and strong but not as weak as in many societies. The author shows feminist traits and ideas because of the desire for the female characters to have equal status with male characters. Emilia and Desdemona challenge the stereotypical portrayal by their husbands. Emilia tells her husband I will not charm my tongue; I am bound to speak (Act 5. Scene 2. Line 196). This statement shows that Emilia is demand the right to be heard by her husband. Emilia's husband wants to silence her, like other women in society, but she is defiant of the manipulative attempts. Desdemona is another female character who challenges the stereotypical women character of naivety and weakness. Desdemona reacts viscously to the attempts of her husband to accuse her of unfaithfulness in marriage. Desdemona tells Othello, ' And you have mercy on me too! I never did Offend you in my life, never loved Casio' (Act 5. Scene 2. Line 66-67). Desdemona is not afraid or naïve to question the thinking and words of her husband. The wife shouts at Othello to express her idea, showing her courage and strength. Desdemona and Emilia do not conform to the stereotypical representation of women as weak and naive as other women in society. The character represents the changing role of women and the empowerment of women. The representation of these women by the author shows that, although the author is male, he understands the importance of the plight and equity of women. The author's approach of assigning female characters gender roles that are against societal norms has an impact on modelling society through undermining gender roles. The author attempts to influence a change in women's position in society by challenging the existing stereotypes of weakness and naivety. Female characterization shows a transition from the traditional woman to a modern woman who has an equal position in society with that of men (Sharma, 2014, p.17).

The author assigns male characters with stereotypical roles, representing the type of men in society. The dominant male stereotypes in Othello are rage, control, manipulation, masculinity, and jealousy that represent masculinity. Male characters in Othello talk and describe women in a prejudicial and discriminatory way. Some men in the story use derogatory words to refer to women, such as fond, black, strumpet, and foul, against social values. Male characters also disrespect and do not value women, as in the case of Othello and Desdemona. Othello says, Come, my dear love, The purchase made, the fruits are to ensue (Act 2. Scene 3. Line 8-9). Othello is implying that after paying a bride price, the 
wife becomes his possession. Payment of dowry is society represented ownership of a woman, making the author show this impression of men. Male characters in Othello also have a controlling approach, especially when dealing with women. Iago and Othello want to control their wives by ensuring they act according to their husbands' wishes. These male characters do not want women to have the freedom to make decisions (Strickler, 2005, p.127). However, their wives challenge some of the control by going against some of the controls. Another stereotype of the male characters is that they are manipulative. Cassio, Iago, and Othello are manipulative based on how they convert stories and scenarios that are unimaginable. Iago shows his manipulative character when he says, Thus do I ever make fool my purse. For I mine own gained knowledge should profane If I would time expend with such a snipe But for my sport and profit. I hate Moor (Act 1. Scene 3. Line 320-324). This statement shows how Iago likes controlling others and how he manipulates them to get an advantage. The representation of male characters shows that the author is honest about presenting their characters without gender bias. The author is male and does not favour male characters by assigning positive gender roles (Strickler, p.121). The author is reinforcing the position of men as heads in society with a wide range of roles and authority. The author gives men an upper hand in decision-making and the domination of women. The text continues the ideology of men's superiority in society, with few women attempting to challenge their authority.

Othello presents various gender roles that represent the changing society. Female characters aim at challenging the traditional negative stereotypes of naïve, weak, and silent. The women challenge male dominance by speaking up and competing with men. The effect of the gender roles is that there is a conflict between male and female characters because of the quest of females to challenge male characters.

\section{CONCLUSION}

In the Elizabethan Era, women's choices were limited. There was a widely held belief that subservient guidelines regarding women's behaviour were defined. The socially-defined subservient roles of the three incredible female characters in Venice's Merchant to men as their wives or daughters clearly showed that women were continually under men's control. Women in the Elizabethan Era faced abundant limitations due to their gender, regardless of their state being ruled by women. Portia, Jessica, and Nerissa seem to be the leading spouses over their male colleagues all through the Merchant of Venice though they were supposed to be submissive, obedient, and silent. The following can be concluded; social practices predominant in modern society determine the masculine and feminine characteristics. Gender study values are based on the social practices prevalent in society.

Feministic values are greatly evident in The Merchant of Venice. William Shakespeare demonstrated a profound and considerable knowledge about the power relation between men and women revealed by their endless tension in the play, in their competition for superiority over each other (Tasmia, 2016). The women challenge their male counterparts by speaking up, conducting themselves, and living differently from traditional gender stereotypes. Female characters challenge male dominance and the traditional negative stereotypes of discrimination, weakness, silence, and naivety. The reversed gender roles' effect creates tension between male and female characters since each assumes superiority. The gender stereotypes in society are represented by the male and female characters dependent on their gender. William Shakespeare advocated for gender equality and deviated from the notion that female characters were inferior.

\section{REFERENCES}

[1] Aro, J. M. (2016). Constructing masculinity: Depiction of the superheroes superman and batman. IUP Journal of English Studies, 11(1), 32. Vol. 11, Iss. 1, (Mar 2016): 32-38.

[2] Calvo, C. (2014). Portia And The Suffragists: The Merchant Of Venice As A "New Woman" Play. Litteraria Pragensia, 24(47). Vol. 24 Issue 47, p48-71. 24p.

[3] Li-hua, H. U. A. N. G. July (2019). On the Otherness of Shylock in The Merchant of Venice. Journal of Literature and Art Studies, 9(7), 661-668. Vol. 9, No. 7, 661-668

[4] Mahon, J. W., \& Mahon, E. M. (Eds.). (2013). The Merchant of Venice: Critical Essays. Routledge.

[5] Nimavat, S. (2017). Shakespeare's Concern about Women: Feminist Perspectives in Shakespeare's Plays. International Journal of Research and Analytical Reviews, 4(2), 145-150. [VOLUME 4 I ISSUE 2 I APRIL - JUNE 2017]

[6] Palahniuk, M. (2015). Gender Issues: Challenges Of The Present. Humanities Bulletin of Zaporizhzhe State Engineering Academy, (60). Issue 60, p73-83. 11p.

[7] Russin, R. (2013). The Triumph of the Golden Fleece: Women, Money, Religion, and Power in Shakespeare's The Merchant of Venice. Shofar, 31(3), 115-130.

[8] Shahid, T. (2013). Exploring the concept of cross-dressing in Shakespeare's plays: uncovering the SHE (Doctoral dissertation, BRAC University).

[9] Shakespeare, W. (2006). The Oxford Shakespeare: Othello: The Moor of Venice (Vol. 21). Oxford University Press.

[10] Sharma, B. (2014). Subalterns in The Merchant of Venice: Interrogating the Postcolonial Reading. IUP Journal of English Studies, Vol. 9, Issue. 4, (Dec 2014): 7-20.

[11] Simms, H. L. (2016). Shakespeare's Dowry: Subjectivity and Resistance in The Taming of the Shrew, Romeo and Juliet, and The Merchant of Venice. UNLV Theses, Dissertations, Professional Papers, and Capstones. 2903.

[12] Strickler, B. (2005). Sex in the city: an ecocritical perspective on the place of gender and race in Othello. Interdisciplinary Studies in Literature and Environment, Vol. 12, No. 2 (Summer 2005), pp. 119-137 (19 pages) Published By: Oxford University Press

[13] Tasmia, F. (2016). Women in Shakespearean comedies: a subversion of gender norms (Doctoral dissertation, BRAC University). 
[14] Walmiki, S. (2017). Shakespeare's "The Merchant of Venice: A Case for Gender Studies. Asian Journal of Multidisciplinary Studies, 5, 3. Vol.5,Issue3,March 2017:33-36

[15] William, S. (2014). The Merchant of Venice. " Издательство"" Проспекm". Volume 54, Number 2, Spring 2014:1-26

Saed Jamil Shahwan was born in Jordan in 1975. He completed my Bachelor and Master degrees in English Literature from Aligarh Muslim University, Aligarh, India in 1998. His Ph.D degree was in English Literature from Rajasthan University, Jaipur, India in2001.

He has 19 years' experience in teaching at universities, eight years teaching at Zarqa Private University in Jordan, and eleven years at University of Hail, where he still works there, in Saudi Arabia. He is interested in writing in different fields of English Literature. He has published many articles in both national and international journals in different countries. Among his published works include: Wordsworth and the 18th Poetical Creative Ability. Advances in Languages and Literary Studies. Vol.10, No 1. "Kindness towards Others in Great Expectations". AWEJ for Translation \& Literary Studies, Volume3, Number2, Pp. 49-55. USA. "Development of Literary Forms in Theatre and Novel during the Victorian Era". International Journal of Applied Linguistics and English Literature. Vol 8, No 5, page 49-51.

Dr. Shahwan, Associate Professor, has memberships in the following journals:

- Editorial board member of the International Journal of Linguistics and Literature (IJLL).

- Editorial board member of the Journal of American Academic Research

- Editorial board member of American Research Institute

- Editorial board member of Global Journal of Language and Linguistics.

- Editorial board member of the International Journal of Literature and Arts. 